\title{
REPRODUCTIVE PATTERNS OF HOLOTHURIA SCABRA (ECHINODERMATA: HOLOTHUROIDEA) IN INDONESIAN WATERS
}

\author{
P. Purwati \\ Research Center for Oceanography, Indonesian Institute of Sciences, \\ Jl.PasirPutih 1, Ancol Timur, Jakarta 14430, Indonesia. \\ email: pradina@indo.net.id
}

\begin{abstract}
During 1993 to 1996, reproductive aspects of Holothuria scabra, one of the commercially important holothurian species in Indonesian waters were studied, which involved populations of Ambon Bay (eastern Indonesian waters), Saugi Island (central Indonesian waters) and Lampung Bay (western Indonesian waters). Those studies were reviewed in this paper, not only to reveal general patterns of reproductive seasons of populations throughout Indonesian waters, but also to provide more knowledge on gonadaltubule-development that has been rarely investigated on Indonesian holothurians. The review showed that the development of gonadal tubules amongst populations of Indonesian $H$. scabra were similar. Those included that: tubules across a gonad grew for one single reproductive cycle, and each tubule had equal opportunity to release their gametes in the same spawning event. These features conformed to general characteristics of this species throughout the world, and were different from the proposed tubule recruitment model of Smiley (1988). Each observed population showed fluctuation on gonad index, and individuals with fecund and/or post spawning gonads were recorded in most sampling occasions, resulting in fluctuation of gonad index. This attribute gave clue to through-year spawning activity with more intense during one or two periods in a year.
\end{abstract}

Keywords: Holothuria scabra, Indonesia, reproductive pattern, tubule development

\section{INTRODUCTION}

Research on holothurian reproduction in Indonesia is limited despite this country has been a major supplier of beche-de-mer to world market. More than 20 holothurian species have been commercially harvested throughout the tropical Indonesian waters (Purwati, 2005), and Holothuria scabra is the most popular among the fishers. Since mid 90's, culture efforts have been initiated with the main objectives are to enhance population recoveries. The efforts begin with conducting reproductive studies to achieve knowledge on reproductive characters and spawning patterns of the populations.

In holothurians, gonad consists of tubules, which protrude from a gonadal basis located at the anterior part of the body cavity. Generally, gonadal tubules grow as the gametes inside develop (Hyman, 1955; Smiley, 1988; Tuwo and Conand, 1990; Purwati, 2001). One model of tubule recruitment has been characterized by Parastichopus californicus (Smiley, 1988) and Holothuria forskali (Sewell et al. 1997; Tuwo and Conand, 1990). Other species including Holothuria leucospilota of tropical Darwin 
waters (Purwati and Luong-van 2003), Actinopyga mauritiana, Holothuria fuscogilva and H.scabra of the Solomon Islands (Ramofafia and Byrne, 2001; Ramofafia et al., 2001), and several species evaluated by Sewell et al.,(1997) exhibit differently in number of tubule groups and synchronization in tubule development across the gonad.

Reproductive cycle of populations at areas near equator tends to demonstrate longer spawning period than those farther away, due to less seasonal fluctuation of water temperature (Pearse, 1968). However, H.leucospilota in tropical Darwin Harbor (Purwati and Luong-van, 2003) shows more restricted spawning period than that in subtropical Heron reef (Franklin, 1980). Whilst, population in north hemisphere subtropical Hong Kong waters lacks of synchronization (Che, 1997).

Three populations of H.scabra that inhabit eastern, central and western Indonesian waters have been examined separately during 1993-1996 by Darsono et al. (1995), Kailola (1997), Susetiono (1996) and Tuwo (1999). Those studies aimed to determine the reproductive season of the populations for culture efforts. This paper scrutinized results of those studies to gain more knowledge on tubule development and reproductive activities. Do those populations show variations in terms of reproductive pattern? Further, reassessing spawning patterns of various populations of $H$.scabra may reveal other tubule recruitment model that may not in agreement with Smiley's (1988). It is hope that this review provides more information on Indonesian holothurians.

\section{METHODS USED IN REVIEWED STUDIES}

Studies on reproductive pattern of H.scabra reviewed in this paper were derived from the works of Darsono et al. (1995) who examined H.scabra of Lampung Bay (western Indonesian waters) from September 1993 to August 1994; Tuwo (1999) who studied population of Saugi Island, South Sulawesi (center Indonesian waters) from November 1995 to October 1996; Kailola (1997) and Susetiono (1996) who investigated population of Ambon Bay, Maluku (eastern Indonesian waters) from June 1995-May 1996 (Fig.1).

Gonad index (GI) was estimated as a weight ratio of fresh gonad and excised body wall in percentage. Studies on Ambon population used 9-20 individuals per month, weighing more than

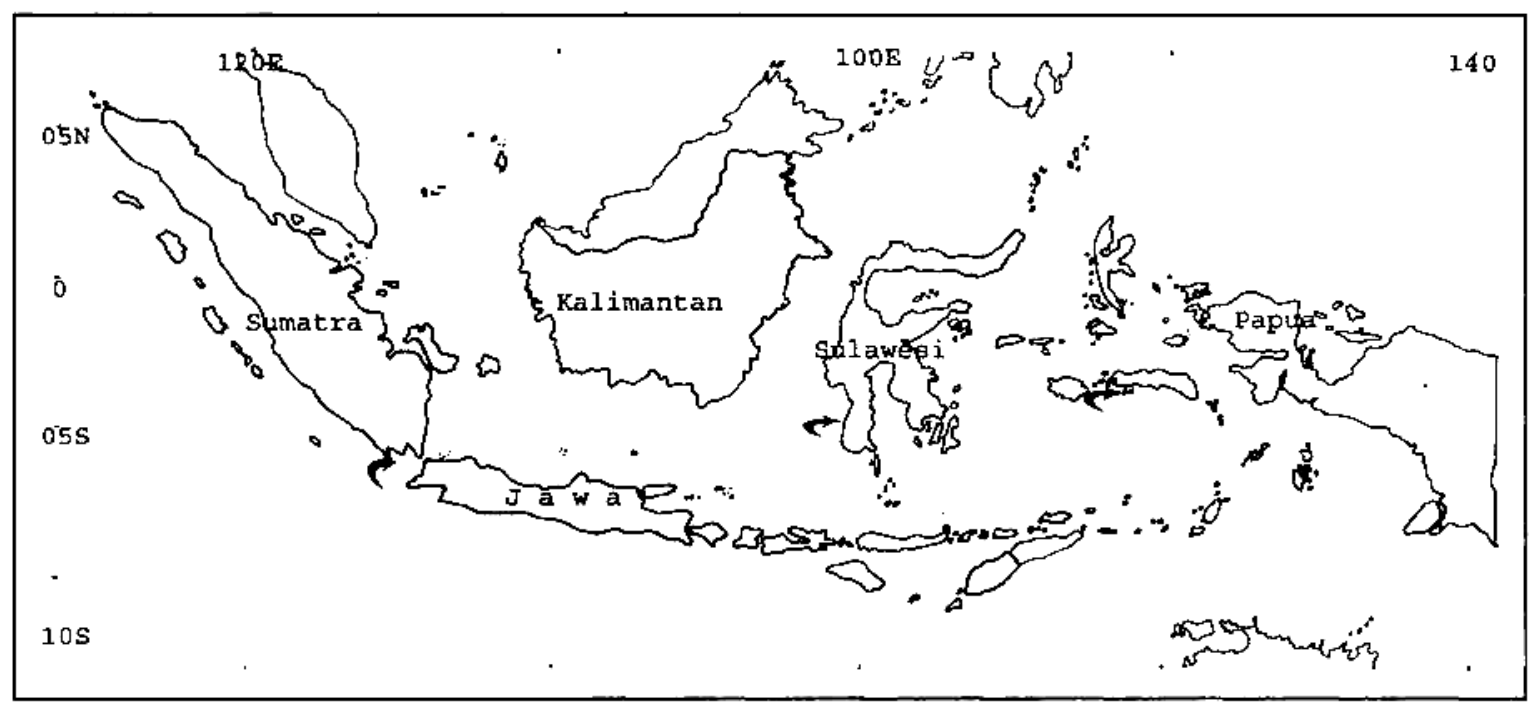

Figure 1. Map of Indonesia showing studied areas (bend arrows) 
200 grams wet body weight. From Lampung Bay and Saugi Island, 30 individuals were collected on monthly basis, but no information on the individual size. It was likely that all individuals examined were in adult stage.

Histological examination on gonads was performed to categorize the maturity stage (detail methods see reviewed papers). Measurement on oocyte diameter was only done on Ambon population.

\section{TUBULE DEVELOPMENT IN INDIVIDUAL LEVEL}

Three populations of H.scabra living in Indonesian waters share common characteristics as shown in Table 1. In some cases, individuals may appear to carry two groups of tubules such as found in a female and a male of Ambon population, in which each group represented early developed and developed tubules, or, fecund and developed stage (Fig. 2). In the population of Saugi Island, the presence of fecund tubules in maturing gonads (Tuwo, 1999) making them possible to release gametes any time in the year. Supporting this evidence was that individuals without visible gonads or carried only afterspawned tubules were easily found. Thus, tubules in a gonad were more likely to be prepared only for a single spawning event. This phenomenon also occurs in H.fuscogilva, Actinopyga mauritiana and H.scabra in Solomon Island (Hamel et al., 2001; Ramofafia and Byrne, 2001), in which spawned or un-spawned tubules are absorbed after the spawning period is over.

Occurrence of few individuals with invisible gonadal tubules in Ambon population led to the indication of resting stage during which tubules disappeared prior to entering the following reproductive cycle, that may not take long. In the Solomon Islands, similar condition among individuals of H.fuscogilva and A.mauritiana are found easily during certain period, because, unlike H.scabra, these populations have synchronous gonad development across population (Ramofafia and Byrne, 2001). In H.leucospilota of Darwin waters which shows synchronous gonad development, resting stage occurs during mid-year for 1-2 months (Purwati and Luong-van, 2003). Other species such as Psolus fabricii (Hamel et al., 1993) and Aslia levefrei (Costello, 1988) on the other hand, maintain and re-grow their after-spawned-tubules.

Tubule recruitment model of H.scabra from Indonesian waters did not correspond to that proposed by Smiley (1988). This population may be added to those inconsistent with Smiley's model, together with H.scabra populating in

Table 1. Features of gonadal tubules and reproductive activities of H.scabra.

\begin{tabular}{|c|c|c|c|}
\hline Gonad condition & $\begin{array}{l}\text { Lampung Bay } \\
\text { (Darsono et al.,1995) }\end{array}$ & $\begin{array}{l}\text { Saugi Island } \\
\text { (Tuwo, 1999) }\end{array}$ & $\begin{array}{r}\text { Ambon Bay } \\
\text { (Susetiono,1996, } \\
\text { Kailola,1997) }\end{array}$ \\
\hline \multicolumn{4}{|l|}{ At individual level } \\
\hline No. of gonads & single & single & single \\
\hline Cohorts of tubules & one & one & one \\
\hline Develop.among tubules & synchronous & synchronous & synchronous \\
\hline Afterspawned tubules & absorbed & absorbed & absorbed \\
\hline \multicolumn{4}{|l|}{ At population level } \\
\hline Gonad development & asynchronous & asynchronous & asynchronous \\
\hline $\begin{array}{l}\text { Presence of after spawn } \\
\text { and/or fecund ind. }\end{array}$ & $\begin{array}{l}\text { throughout the } \\
\text { year }\end{array}$ & throughout the year & throughout the year \\
\hline Type of breeding & continues & continues & continues \\
\hline Spawning peaks & March-May/Nov.Jan & Oct-Feb/Apr-July & Oct-Des/March-April \\
\hline GI female to male & not available & not available & Greater \\
\hline
\end{tabular}



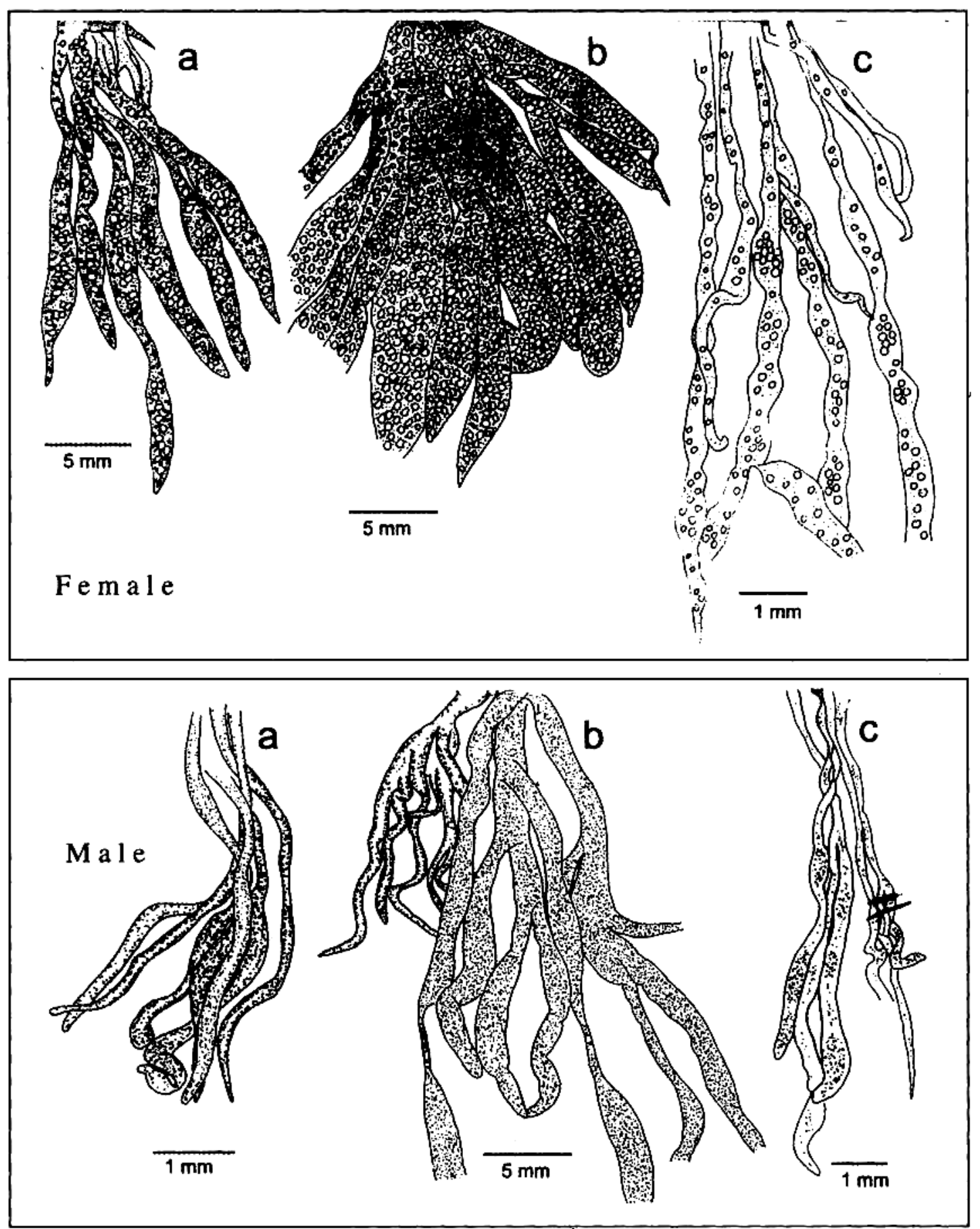

Figure 2. Gonadal tubules of $H$. scabra, representing, a: early stage; b: fecund; c: after spawned tubules (drawn under camera lucida)

Calatagan, the Philippines (Che and Gomez, 1985) and New Caledonian lagoon (Conand, 1993), and also other species H.leucospilota from Darwin waters (Purwati and Luong-van, 2003) and those assessed by Sewell et al. (1997) and Ramofafia and Byrne (2001), including H.fuscogilva and A.mauritiana.
Since species excluding Smiley's model have been growing, and similarities among those species have been revealed, therefore, other model should be proposed that covered mainly aspidochirote species. The main principles of the proposed model are: 
- An individual only possesses single tuft of tubules which develops synchronously across gonad

- Tubules are prepared only for one single cycle, after-spawned tubules are reabsorbed and new tubules grow in every reproductive cycle

- It takes up to 12 months for gonadal tubules to reach fecundity

Population showing synchronous gonad development provided easy estimation of required time taken for one reproductive cycle. The occurrence of resting stage during which gonad disappeared from the population offered easy prediction for not only the commencing of reproductive cycle, but also the time required for gametogenesis. Example is H.leucospilota from tropical Darwin Harbor (Purwati and Luong-van, 2003). Such ease did not seem to be offered by most H.scabra populations.

\section{REPRODUCTIVE CYCLE OF THE POPULATIONS}

Reports on Lampung and Saugi populations presented combined GI rather than separated male and female GI. This may cause inaccuracy in the fluctuation, because males may initiate spawning, and spawn longer in several cases such as in S.mollis (Sewell, 1990). Further, higher female GI then male as demonstrated in Ambon population, could not be determined in the other two populations (Fig. 3 - 4). These kinds of sex capacities have also been reported to occur in most holothurians including H.scabra of New Caledonian Lagoon (Conand, 1993) and Krusadi Is., Gulf of Myanmar (Khrisnaswamy and Krishnan, 1967), and other species such as H.fuscopunctata, H.nobilis, Actinopyga mauritiana, A.echinites and Thelenota ananas (Conand, 1993).

Heterogeneity in gonadal stages in any time of the year, which reflected asynchronous development among individuals in the population was prominent in H.scabra of Indonesian waters. Monthly percentage of fecund individuals in Ambon population had been estimated 5.0$45.0 \%$ (average $16.1 \%$ ) and after spawned individuals were $5.0-67.0 \%$ (average 21.8\%) of the total collected individuals. The highest number of fecund individuals had been reported to occur in April. For Lampung population, the range was $0-50.0 \%$ and $0-16.7 \%$ for fecund and after spawned individuals, respectively. Percentage of fecund individuals was maximal in June, November and March.

Heterogeneity in gonad stages was also indicated by a great variation on GI values in each sampling occasion (Fig. 3-4). Range of monthly GI was relatively wide in each sex of Ambon population and combined GI of Lampung population (no information for Saugi population).

GI with the smallest and largest standard deviation (SD) showed in female GI $0.4 \% \pm$ $0.2 \mathrm{SD}-5.1 \% \pm 6.4$ (SD mostly exceeded $2.0 \%$ ) and male GI $0.3 \pm 0.2 \%-2.3 \pm 4.5 \%$ (SD mostly more than 1.0\%) for Ambon population. Combined GI of Lampung with smallest and largest SD was $0.1 \pm 0.1 \%$ andO.9 $\pm 1.1 \%$. Large variation has also been reported in H.scabra of New Caledonian Lagoon with a range of $5.4 \pm 2.4 \%$ in male and $7.2 \pm 3.8 \%$ in female (Conand, 1993), and also the same species inhabiting Calatagan, Batangas waters, the Philippines (Che and Gomez, 1985).

GI of Lampung population showed lower than those of Ambon and Saugi populations (Fig. 3). It was not clear yet, if this indicated low reproductive capacity. The GI average of Lampung population seemed more fluctuated than that of Ambon and Saugi population (Fig. 3-6). In Ambon population, maximum value of GI following with a sharp drop occurred in October (which decreased until December). Change in average of oocyte diameter of Ambon population supported the tendency of GI (Fig. 4). It maximized in October followed with abruptly decreased until December. It also occurred in June, which was possibly followed with sharp drop until August. For Saugi population, maximum value was reached in April (sharply drop to July) and October (drop to January). Lampung population demonstrated maximum value occurring in November (drops to January) and March (drop to May). However, intensive spawning was likely to occur in June-July as well. 


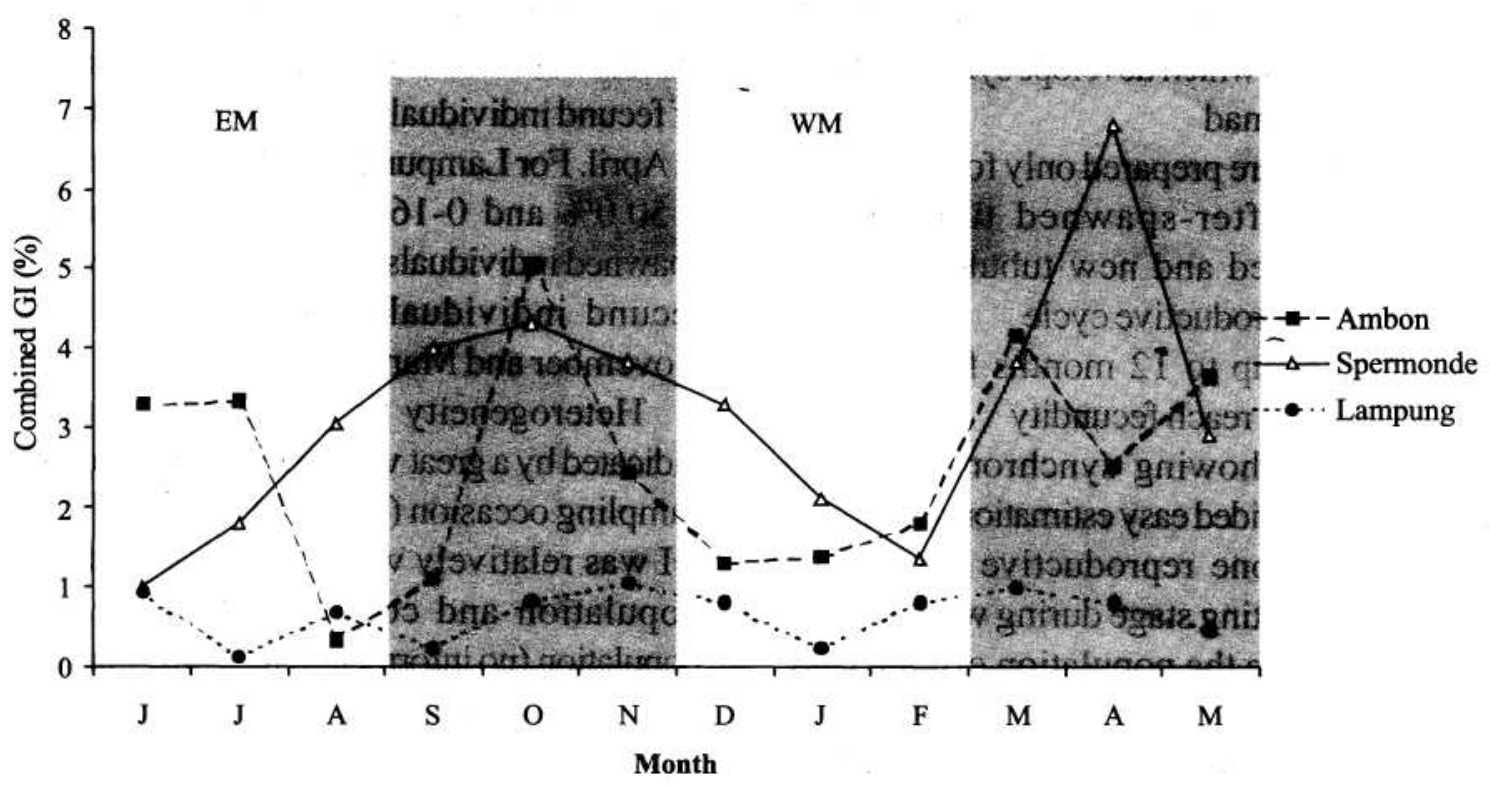

Figure 3. Combined GI's of three populations of $H$. scabra inhabiting Indonesian waters. EM: east monsoon; WM: west monsoon.

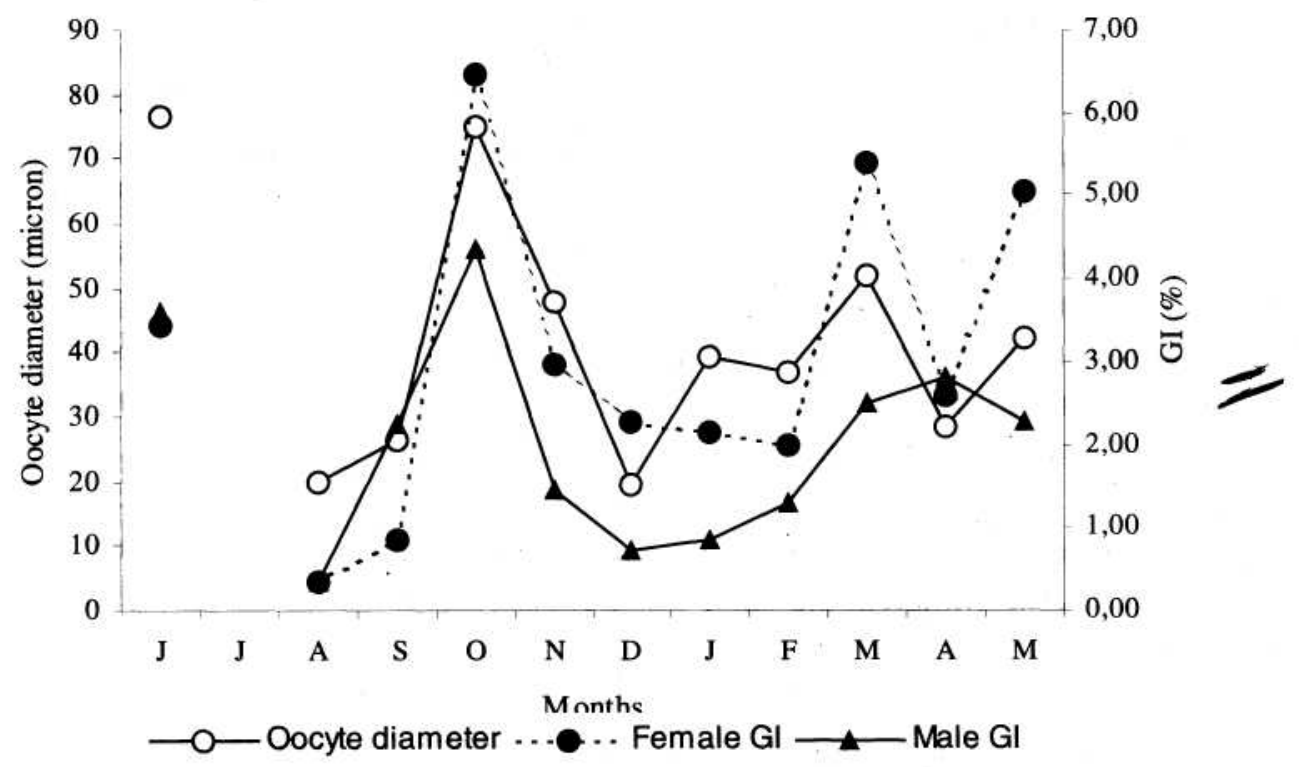

Figure 4. Changes in average of GI and oocyte diameter in H.scabra population of Ambon (Susetiono, 1996; Kailola, 1997).

Indonesia is dominated with west (from December to February) and east monsoon (from June to August). Ambon shows similar condition with Saugi Island, but different from Lampung. During west monsoon, rainfall is minimum, water temperature and salinity are maximum, and sea state is relatively rough in the first two areas. During east monsoon, rainfall maximizes, water temperature and salinity reach maximum and sea state is rough. Lampung is in the other way around: west monsoon brings water temperature and salinity to minimum, and east monsoon brings those factors maximizing. During transitional season, all areas show relatively calm sea state. Considering these water conditions, spawning of the populations of Ambon and Saugi island occurred during transitional season, when the waters were relatively calm, and the temperature 
Table 2. Spawning pattern of H.scabra throughout the world

\begin{tabular}{|l|l|l|l|}
\hline \multicolumn{1}{|c|}{ Geography } & $\begin{array}{c}\text { Spawning } \\
\text { pattern }\end{array}$ & \multicolumn{1}{|c|}{ Spawning season/peaks } & \multicolumn{1}{|c|}{ References } \\
\hline Solomon Is. & continuous & September-October & Battaglene(1999) \\
\hline Tuticorin, India & & March-may and Oct-Dec & James (1999) \\
\hline Calatagan, Philippines & continuous & July-August; Jan-Feb. & Che and Gomez (1985) \\
\hline New Caledonian lagoon & continuous & Sept and Dec-Jan & Conand (1993) \\
\hline Moreton Bay, Australia & seasonal & November-Feb. & Morgan (2000) \\
\hline $\begin{array}{c}\text { Gulf of Myanmar } \\
\text { Indonesian waters } \\
\text { - Lampung } \\
\text { - Saugi }\end{array}$ & continuous & July-Oct. & $\begin{array}{l}\text { Khrishnaswamy and Krishnan } \\
\text { (1967) }\end{array}$ \\
\hline Ambon & $\begin{array}{l}\text { Continuous } \\
\text { Aprono et al. (1995) Tuwo } \\
\text { (1999) Susetiono (1996) and } \\
\text { Kailola (1997) }\end{array}$ \\
\hline
\end{tabular}

altered to maximum or minimum. Spawning seemed more intense when season altered to west monsoon when water temperature went up.

In Lampung, prediction on spawning season was rather difficult. At least, GI dropped in relatively similar degree from November to January coinciding with the beginning of west monsoon when the water temperature went down, and from March to May during transitional season to east monsoon with relatively calm waters and increasing temperature.

Asynchronous progression of gonads across population appears also in H.scabra from tropical Solomon Island (Battaglene, 1999; Ramofafia and Byrne, 2001), Hongkong (Che and Gomez, 1985) and New Caledonian Lagoon (Conand, 1993). At Tuticorin, India, reproductive season of H.scabra occurs during March-May (major) and October-December (minor) (James, 1989). While in the Solomon Island, the population spawns during September and October (Battaglene, 1999).

Time required for one cycle of reproduction had not been uncovered in the three studied populations. Same species inhabiting subtropical Moreton Bay (Australia), on the other hand, shows synchronous gonad development and the spawning occurs only during certain periods (November-February), while resting stage takes in February (Morgan, 2000). In account of that, time taken for one reproductive cycle may be estimated up to one year, which starts in March or April.

\section{CONCLUSION}

H.scabra populating in Indonesian waters release gametes throughout the year. Such fluctuation on GI showed in three populations brings up ambiguity, whether or not gamete release peaks during certain period. Moreover, inter-year variation on spawning peaks is common to occur amongst tropical holothurian species. In account on these features, extending sampling period is necessary to a minimum of two reproductive cycles (2 years). However, collecting sample may be a problem due to limited natural stocks. If possible, all larva sampling will be useful not only in estimating spawning peak but also predicting recruitment.

Acknowledgments. This paper is part of the holothurian project supported by Competitive Research Program LIPI Census of Marine Life 2005. I wish to thank Dr. A.G Ilahude and Ir. L.F. Wenno for their valuable suggestions, mainly on physical oceanography information. Thanks are also addressed to Dr. A. Syahailatua who critically read the manuscript.

\section{REFERENCES}

Battaglene, S.C. 1999. Culture of tropical sea cucumber for stock restoration and enhancement. Naga, 1CLARM Quarterly, 22(4): 5-11.

Che, R.G.O. 1997. Reproductive cycle of the Holothuria leucospilota Brandt (Echinodermata: Holothuroidea) in Hong Kong and the role of 
body tissues in reproduction. Asian Mar. Biol., 7:115-132.

Che, R.GO. and E.D. Gomez. 1985. Reproductive periodicity of Holothuria scabra Jaeger at Calatagan, Batangas, Philippines. Asian Mar. Biol., 2:21-30.

Conand, C. 1993. Reproductive biology of the holothurians from the major communities of the New Caledonian Lagoon. Mar. Biol., 116:439-450.

Costello, J. 1988. Reproductive cycle, development and recruitment of two geographically separated populations of the dendrochirote holothurian Aslia lefevrei. Mar. Biol., 99:535545.

Darsono, P., Sukarno and Notowinarto. 1995. Siklus reproduksi teripang pasir (Holothuria scabra) Jaeger (Holothuroidea, Aspidochirota), di perairan Teluk Lampung. Kongres Nasional Biology XI, Depok.

Franklin, S. E. 1980. The reproductive biology and some aspects of the population ecology of the holothurian Holothuria leucospilota (Brandt) and Stichopus chloronotus (Brandt). The Univ. Sydney, Sydney: 250 pp.

Hamel, J.F., C. Conand, D.L. Pawson and A. Mercier. 2001. The sea cucumber Holothuria scabra (Holothuroidea, Echinodermata): its biology and exploitation as beche-de-mer. In: Southwards, P.A. Tyler, J.S. Young, and Fuiman (eds). Advances in Marine Biology. Academic Press, Tokyo, 129-223.

Hamel, J.-F., J.H. Himmalman and L. Duffesne. 1993. Gametogenesis and spawning of the sea cucumber Psolus fabricii (Buben and Koren). Bio. Bull, 184:125-143.

Hyman, L.H. 1955. Echinodermata. The Invertebrates. McGraw Hill Book Co., New York; 121-244.

James, D.B. 1989. Hatchery and culture technology for the sea cucumber, Holothuria scabra in India. Naga, the ICLRAM Quart, 22(4): 12-16.

Kailola, W. M. 1997. Siklus reproduksi teripang pasir (Holothuria scabra). Thesis SI, Fak. Perikanan. UNPATTI, Ambon, 57 pp.
Khrisnaswamy, S. and S. Krishnan. 1967. A report on the reproductive cycle of holothuria Holothuria scabra Jaeger. Current Sci. Ass.,:155-156.

Morgan, A.D. 2000. Aspects of the reproductive cycle of the sea cucumber Holothuria scabra (Echinodermata: Holothuroidea). Bull. Mar. Sc, 66(1): 47-57.

Pearse, J.S. 1968. Pattern of reproductive periodicity in four species of Indo-Pacific Echinoderms. Proceeding of the Indian Academic of Science. Section B. The Academy, Hebbal, Bangalor; 247-279.

Purwati, P. 2001. Reproduction in Holothuria leucospilota Clark 1920 in tropical Darwin waters, NT Australia. MSc. Thesis, Northern Territory Univ., Darwin: 147.

Purwati, P. 2005. Teripang Indonesia: komposisi jenis dan sejarah perikanan. Oseana 30(1): 12 pp.(in press)

Purwati, P. and J.T. Luong-van. 2003. Sexual reproduction in fissiparous holothurian species Holothuria lecospilota Clark 1920 (echinodermata: Holothuroidea). SPC Beche-demer Info. Bull, 18:33-38.

Ramofafia, C., and M. Byrne. 2001. Assessment of the tubule recruitment model in three tropical aspidochirote holothurians. SPC Beche-demer Info. Bull, 15:13-16.

Ramofafia, C, M. Byrne and C. Battaglene. 2001. Reproductive biology of the intertidal sea cucumber Actinopyga mauritiana in the Solomon Islands. J. Mar. Biol. Ass. UK, 81:523-521.

Sewell, M.A. 1990. Reproductive of the temperate aspidochirote Stichopus mollis (Echinodermata: Holothuroidea) in New Zealand. Ophelia, 35(2): 103-121.

Sewell, M.A., PA. Tyler, J.S. Young and C. Conand. 1997. Ovarian development in the class Holothuroidea: a reassesment of the tubule recruitment model. Bio. Bull, 192:1726.

Smiley, S. 1988. The dynamic of oogenesis and the annual ovarian cycle of Stichopus 
califomicus (Echinodermata: Holothuroidea). Bio. Bull, 175:79-93.

Susetiono. 1996. Pembenihan kima di Tual, Maluku Tenggara tahap II dan Reproduksi teripang di Ambon. Laporan SDL P2O LIPI,Ambon: 19-34

Tuwo, A. 1999. Reproductive cycle of the holoturian Holothuria scabra in Saugi Island,
Spemonde Archipelago, Southwest Sulawesi, Indonesia. SPC Beche-de-mer Info.Bull.,11:9-12.

Tuwo, A. and C. Conand. 1990. Reproductive biology of the Holothuria forskali (Echinodermata). J. Mar Bio. Ass. UK., 72:745-758. 